\title{
GIS-based Effect Assessment of Soil Erosion Before and After Gully Land Consolidation: A Case Study of Wangjiagou Project Region, Loess Plateau
}

\author{
LIU Yansui ${ }^{1,2}$, GUO Yanjun ${ }^{2,3}$, LI Yurui ${ }^{2}$, LI Yuheng ${ }^{1,2}$ \\ (1. College of Resources Science and Technology, Beijing Normal University, Beijing 100875, China; 2. Institute of Geographic Sci- \\ ences and Natural Resources Research, Chinese Academy of Sciences, Beijing 100101, China; 3. University of Chinese Academy of \\ Sciences, Beijing 100049, China)
}

\begin{abstract}
The Loess Plateau is one typical area of serious soil erosion in the world. China has implemented 'Grain for Green' (GFG) project to restore the eco-environment of the Loess Plateau since 1999. With the GFG project subsidy approaching the end, it is concerned that farmers of fewer subsidies may reclaim land again. Thus, 'Gully Land Consolidation Project' (GLCP) was initiated in 2010. The core of the GLCP was to create more land suitable for farming in gullies so as to reduce land reclamation on the slopes which are ecological vulnerable areas. This paper aims to assess the effect of the GLCP on soil erosion problems by studying Wangjiagou project region located in the central part of Anzi valley in the middle of the Loess Plateau, mainly using the revised universal soil loss equation (RUSLE) based on GIS. The findings show that the GLCP can help to reduce soil shipment by $9.87 \%$ and it creates more terraces and river-nearby land suitable for farming which account for $27.41 \%$ of the whole study area. Thus, it is feasible to implement the GLCP in places below gradient $15^{\circ}$, though the GLCP also intensifies soil erosion in certain places such as field ridge, village land, floodplain, natural grassland, and shrub land. In short, the GLCP develops new generation dam land and balances the short-term and long-term interests to ease the conflicts between economic development and environmental protection. Furthermore, the GLCP and the GFG could also be combined preferably. On the one hand, the GFG improves the ecological environment, which could offer certain safety to the GLCP, on the other hand, the GLCP creates more farmland favorable for farming in gullies instead of land reclamation on the slopes, which could indirectly protect the GFG project.
\end{abstract}

Keywords: gully land consolidation; land-resource engineering; revised universal soil loss equation (RUSLE); effect assessment; Loess Plateau

Citation: Liu Yansui, Guo Yanjun, Li Yurui, Li Yuheng, 2015. GIS-based effect assessment of soil erosion before and after gully land consolidation: a case study of Wangjiagou project region, Loess Plateau. Chinese Geographical Science, 25(2): 137-146. doi: $10.1007 / \mathrm{s} 11769-015-0742-5$

\section{Introduction}

The Loess Plateau, as one typical area of serious soil erosion in China has received much attention from both the government and academic spheres (Yang and $\mathrm{Yu}$, 1992; Ritsema, 2003; Ostwald and Chen, 2006; Fu et al., 2011; Chen et al., 2013; Hou et al., 2014). Around 2000 years ago, the Loess Plateau was mainly covered by forest with little soil erosion, however, the Huanghe (Yellow) River started to become turbid due to soil erosion about 600 years later (Wang et al., 2006; Bettinger et al., 2007). The major reason for soil erosion in the Loess Plateau was reclamation for farming land and low vegetation coverage (Fu, 1989). To cope with the ever increasing ecological problems, the Chinese Central Government implemented 'Grain for Green' (GFG) pro-

Received date: 2014-06-03; accepted date: 2014-09-05

Foundation item: Under the auspices of National Natural Science Foundation of China (No. 41130748, 41471143)

Corresponding author: LI Yurui. E-mail: liuys@igsnrr.ac.cn

(C) Science Press, Northeast Institute of Geography and Agroecology, CAS and Springer-Verlag Berlin Heidelberg 2015 
ject in the Loess Plateau since 1999 (Wang et al., 2013; Liu et al., 2014), and the ecological environment of the Loess Plateau has recovered to some extent (Deng et al., 2012; Zhou et al., 2012). Owning to the GFG project, the vegetation cover increased significantly (Zhou et al., 2008; Miao et al., 2012) as the soil and water erosion decreased consistently (Liu et al., 2010; Zhou et al., 2012). However, it is unclear that if the GFG project benefits all local households and improves rural living conditions (Uchida et al., 2007; Bennett, 2008; Liang et al., 2012). Particularly, as the government adjusts the subsidies for the GFG project, it is concerned that farmers who get less subsidies may reclaim land again (Cao et al., 2009). Thus, how to deal with the conflicts between agricultural development and ecological protection in the Loess Plateau needs particular attention (Guo et al., 2014).

In 2010, the 'Gully Land Consolidation Project' (GLCP) was initiated in some counties of Yan'an City, Shaanxi Province, which is located in the central Loess Plateau. Later, the project was extended to the whole Yan'an City. The GLCP as an important land-resource engineering aims to approach a way to settle the conflicts between agricultural development and ecological protection in the Loess Plateau especially when the GFG subsidies are getting less. The core of the GLCP is to create more farming land in gullies so as to reduce land reclamation on the slopes which are ecological vulnerable areas. Then, the GLCP could help to improve the quality of land eco-system in the Loess Plateau. Gullies consolidation to create farmland has proved some effects, such as saving water, developing rural economy and reducing natural disasters (Long et al., 2010; Liu et al., 2013; Liu and Li, 2014). However, it still needs further study to investigate the GLCP effect on the soil erosion problems both qualitatively and quantitatively. Thus, this paper aims to analyze the changes of soil erosion on the Loess Plateau before and after the GLCP, and this study further reveals how the GLCP helps to ease the conflicts between agricultural development and ecological protection.

\section{Study Area and Methodology}

\subsection{Study area}

The Wangjiagou project region $\left(36^{\circ} 06^{\prime} 22^{\prime \prime}-36^{\circ} 09^{\prime} 49^{\prime \prime} \mathrm{N}\right.$, $109^{\circ} 36^{\prime} 12^{\prime \prime}-109^{\circ} 40^{\prime} 25^{\prime \prime} \mathrm{E}$ ) is located in the northeast of
Fuxian County, Yan'an City, Shaanxi Province, China (Fig. 1). It covers a total area of 281.3 ha and lies in the central part of Anzi valley in the middle of the Loess Plateau, featured with intertwined terrain, ridge sand mound. The average annual temperature, sunshine hours, frost-free period, precipitation are $7.1^{\circ} \mathrm{C}-9.0^{\circ} \mathrm{C}$, 2032-2428 h, $130 \mathrm{~d}, 500-600 \mathrm{~mm}$, respectively. There is one administrative village named Anzi Village which consists of eight natural villages. The GLCP in Wangjiagou project region started in April, 2012 and ended in March, 2013.

\subsection{Methodology}

This paper tries to assess the soil erosion by using GIS-based revised universal soil loss equation (RUSLE) model in Wangjiagou project region in the Loess Plateau. The universal soil loss equation (USLE) (Wischmeier and Smith, 1978) is widely used to monitor soil erosion because of its applicability and reliability (Lee, 2004; Fu et al., 2011). The GIS is widely employed in USLE/RUSLE to assess soil erosion (Fistikoglu and Harmancioglu, 2002; Erdogan et al., 2007; Irvem et al., 2007; Bonilla et al., 2010; Chen et al., 2011; Prasannakumar et al., 2012). The digital elevation model (DEM) established by data from field-measured elevation points and contours is more employed for relatively smaller areas (De Bruin and Stein, 1998; Liu et al., 2003; Li et al., 2010). This study used high-density field-measured elevation points to establish DEM which was precise enough for the study.

$A=R \times K \times L S \times C \times P$

where $A$ denotes the average annual soil loss caused by sheet and rill erosion ( $\mathrm{t} /(\mathrm{ha} \cdot \mathrm{yr})) ; R$ indicates the rainfall erosivity factor $(\mathrm{MJ} \cdot \mathrm{mm} /(\mathrm{ha} \cdot \mathrm{h} \cdot \mathrm{yr})) ; K$ is the soil erodibility factor $(\mathrm{t} \cdot \mathrm{h} \cdot \mathrm{ha} /(\mathrm{ha} \cdot \mathrm{MJ} \cdot \mathrm{mm})) ; L S$ is the slope length $\&$ steepness factor (dimensionless); $C$ is the land cover and management factor (dimensionless, ranging from 0 to 1 ); $P$ is the support conservation practice factor (dimensionless, ranging from 0 to 1 ). The implementation of the RUSLE was conducted in the theoretical framework. The value of every single factor was evaluated and stored in a raster dataset with the resolution of $1 \mathrm{~m}$, and then the parameters of the RUSLE were combined to the result raster layer $A$ according to the RUSLE Equation (1).

The $R$ factor value was calculated according to the 


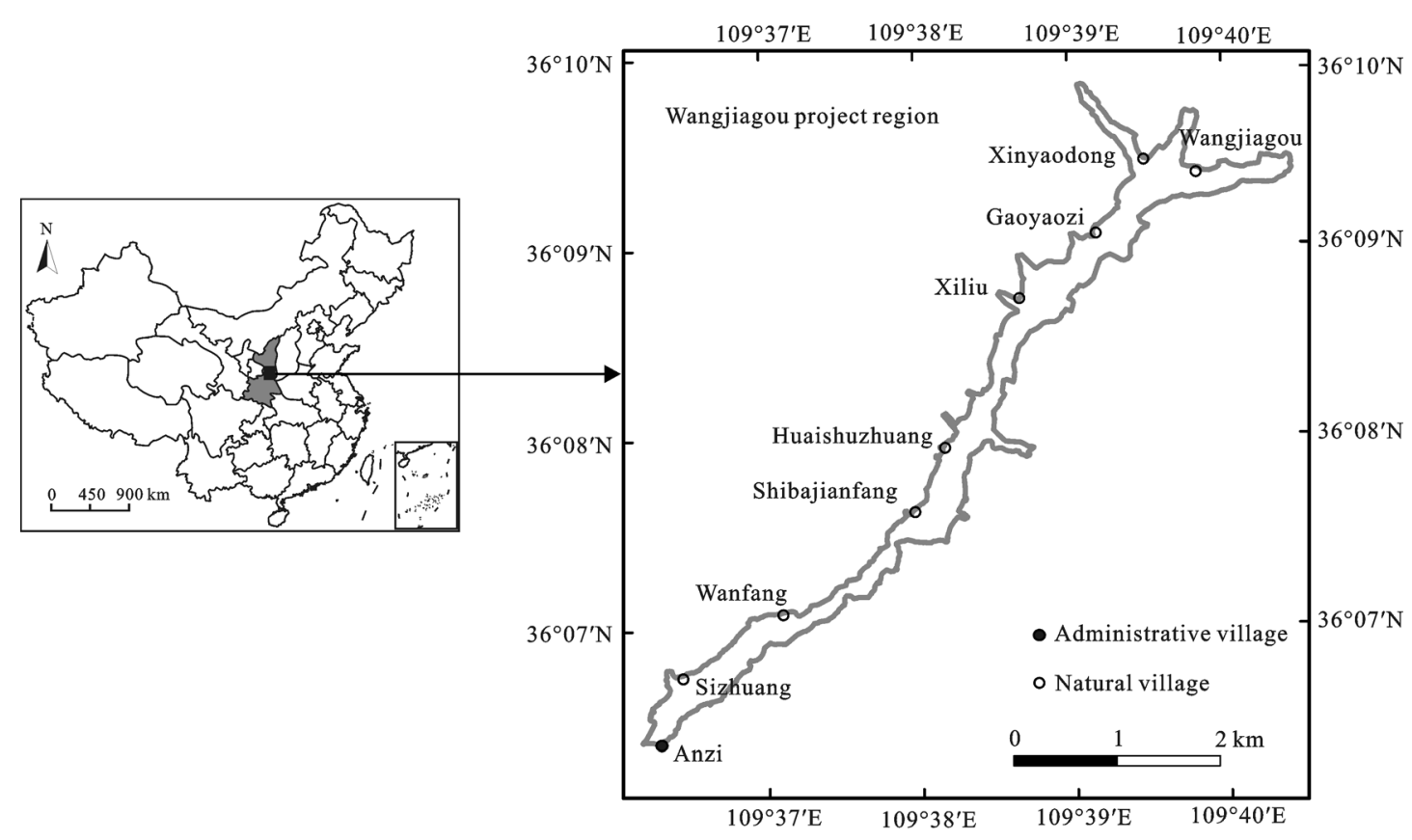

Fig. 1 Location of study area and its contained village

rainfall data in Equation (2) (Wischmeier et al., 1971):

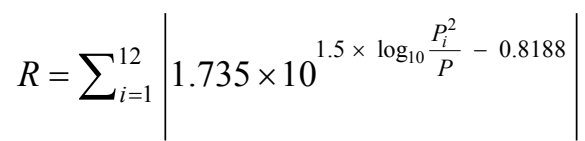

where $R$ denotes the rainfall erosivity factor; $P_{i}$ is average month rainfall; $P$ is annual rainfall.

The $K$ factor value was calculated according to the way proposed by Liu et al. (1999):

$K=7.594\left\{0.0034+0.0405 \exp \left[\left(\log D_{\mathrm{g}}+1.659\right) / 0.7101\right]\right\}$

$D_{\mathrm{g}}=\exp \left(0.01 \sum f_{i} \ln m_{i}\right)$

where $K$ denotes the soil erodibility factor (th $\cdot h \mathrm{ha} /(\mathrm{ha} \cdot \mathrm{MJ} \cdot \mathrm{mm})$ ); $D_{\mathrm{g}}$ is the geometric mean diameter of soil particles $(\mathrm{mm}) ; m_{i}$ is the geometric mean diameter below the $i$ th grade $(\mathrm{mm}) ; f_{i}$ is the quality percentage of the $i$ th grade $(\%)$. The main soil type in Wangjiagou project region is loessial soil, and $m_{i}$ and $f_{i}$ of loessial soil refer to the values from Zhao (1989).

The $L$ and $S$ factor values were derived from the DEM and combined to a single $L S$ factor as shown in Fig. 2. The DEM was first revised in ArcGIS for accuracy enhancement. Then, reclassify 1 was calculated according to Equation (5) suggested by Liu et al. (2000) about steep slope equation on the Loess Plateau while reclassify 2 and Raster calculation 1 were calculated according to Equation (6) from USLE (Wischmeier et al., 1971; Wischmeier and Smith, 1978):

$$
S=\left\{\begin{array}{rr}
10.8 \sin \theta+0.03 & \theta<5^{\circ} \\
16.8 \sin \theta-0.50 & 5^{\circ} \leq \theta<10^{\circ} \\
21.9 \sin \theta-0.96 & \theta \geq 10^{\circ}
\end{array}\right.
$$

where $S$ denotes slope steepness factor, and $\theta$ is the gra$\operatorname{dient}\left({ }^{\circ}\right)$.

$$
L=(l / 22.13)^{n} \quad n\left\{\begin{array}{rr}
0.2 & \theta<0.57^{\circ} \\
0.3 & 0.57^{\circ} \leq \theta<1.72^{\circ} \\
0.4 & 1.72^{\circ} \leq \theta<5.14^{\circ} \\
0.5 & \theta \geq 5.14^{\circ}
\end{array}\right.
$$

where $L$ denotes slope length factor; $\theta$ is the gradient $\left.{ }^{\circ}\right) ; l$ is pixel slope length calculated by eight directions pour point; and $n$ denotes slope length exponent.

The $C$ factor value and the $P$ factor value were both derived from the land use types combined with field investigation, which was reclassified according to the experimental values of the RUSLE factors (Table 1). Corn is the main local crop planted in the study area due to its labor-saving as few potato and soybean were planted, so the $C$ value of cropland was set to 0.28 according to the value from Zhang et al. (2001). The forest in the study area is deciduous broad-leaved forest and has a high vegetation coverage which was partly created 


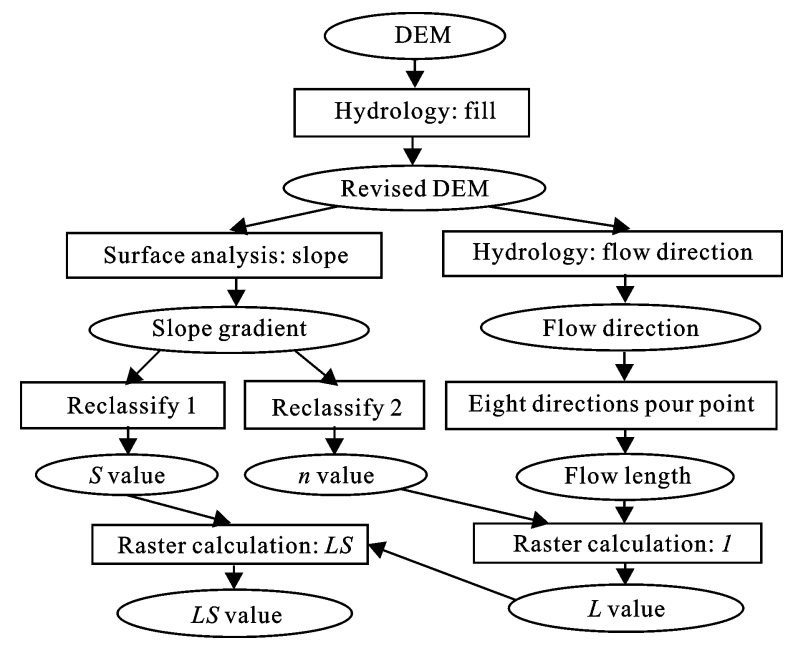

Fig. 2 Work flow for determination of slope length \& steepness $(L S)$ factor

by the GFG. Based on the study of Zhang et al. (2003), the $C$ values of closed forest land, shrub land, and other forest land were set to $0.004,0.083$, and 0.144 , respectively. The $C$ values of natural grassland and other grassland were set to 0.44 according to the parameters from Qin et al. (2009) as grassland lacks maintenance and the grass on it grows arbitrarily. Hydraulic structure, field ridge, and floodplain are covered with sparse grass, thus, they were set to 0.44 like natural grassland and other grassland. The $P$ values of natural vegetation and slope cropland were set to 1 . The $P$ values of river-nearby land and terrace were set to 0.1 according to the results of Tong et al. (2006). The $P$ values of rural road land and irrigation and drainage land were set to 0.01 as they have been paved or hardened. Pond was also set to 0.01 as it is covered by water. The $P$ values of other lands without conservation measures were set to 1 .

\subsection{Data source and preparation}

The data consists of before-consolidation data and afterconsolidation data. The before-consolidation data for topography includes field-measured 8144 elevation points with contours. The after-consolidation data includes 11875 elevation points which incorporate fieldmeasured 8144 elevation points and new-added 3731 points for outlining the intact border of every leveling field plot. The land use types of before-consolidation and after-consolidation were made respectively based on the current land use map $(1: 10000)$ and land use planning map $(1: 10000)$. The precipitation data over the last 30 years were collected from local meteorological station and provided by local meteorological bureau.

The triangular irregular network (TIN) was formed and computed by using the software package ESRI ArcGIS based on acquired elevation points with contours. The final result was examined and revised until the validation of the two before- and after- consolidation TINs succeeded in meeting the accuracy. Then, TINs were converted to before- and after- consolidation DEM with the resolution of $1 \mathrm{~m}$. The two DEMs were further revised in ArcGIS for accuracy enhancement. Based on the current land use map $(1: 10000)$ and land use

Table 1 Parameters of land cover and management $(C)$ factor value and support conservation practice $(P)$ factor value

\begin{tabular}{|c|c|c|c|c|}
\hline First-grade land type & Code & Second-grade land type & C & $P$ \\
\hline \multirow{3}{*}{ Cropland } & 11 & Slope cropland & 0.28 & 1 \\
\hline & 12 & Terrace & 0.28 & 0.1 \\
\hline & 13 & River-nearby land & 0.28 & 0.1 \\
\hline \multirow{3}{*}{ Forest land } & 21 & Closed forest land & 0.004 & 1 \\
\hline & 22 & Shrub land & 0.083 & 1 \\
\hline & 23 & Other forest land & 0.144 & 1 \\
\hline \multirow{2}{*}{ Grassland } & 31 & Natural grassland & 0.44 & 1 \\
\hline & 32 & Other grassland & 0.44 & 1 \\
\hline \multirow{4}{*}{ Construction land } & 41 & Village land & 1 & 1 \\
\hline & 42 & Mine land & 1 & 1 \\
\hline & 43 & Rural road land & 1 & 0.01 \\
\hline & 44 & Hydraulic structure & 0.44 & 1 \\
\hline \multirow{4}{*}{ Other land } & 51 & Pond & 1 & 0.01 \\
\hline & 52 & Floodplain & 0.44 & 1 \\
\hline & 53 & Irrigation and drainage land & 1 & 0.01 \\
\hline & 54 & Field ridge & 0.44 & 1 \\
\hline
\end{tabular}


planning map (1: 10000), cropland was subdivided into three classes: slope cropland, terrace and river- nearby land according to the slope map derived from DEM and whether it is close to the river channel (Fig. 3). The final land use types were shown in Table 1. The gradient of slope cropland was more than $5^{\circ}$ while terrace and river-nearby land were below $5^{{ }^{(1)}}$.

\section{Results}

\subsection{Soil erosion in study area}

The mean values of all parameters of the RUSLE as well as the mean amount of soil erosion for each pixel before and after consolidation are presented in Table 2 . The mean value of soil erosion modulus in the whole project region decreases from $551.87 \mathrm{t} /\left(\mathrm{km}^{2} \cdot \mathrm{yr}\right)$ before consolidation to $497.39 \mathrm{t} /\left(\mathrm{km}^{2} \cdot \mathrm{yr}\right)$ after consolidation. The total amount of soil shipment decreases from $1552.41 \mathrm{t} / \mathrm{yr}$ to $1399.16 \mathrm{t} / \mathrm{yr}$. The most significant change in all the parameters is that $P$ mean value decreases from 0.67 to 0.37 . Conversely, the mean values of $L S$ and $C$ increase but at a small range.

To gain more information about the soil erosion intensity, raster layer $A$ was reclassified into six grades in ArcGIS (Table 3). The proportion of slight erosion ranked first, accounting for $85.74 \%$ of the whole project region area before rehabilitation, and still ranks first after consolidation even with an increase up to $91.18 \%$. The area of mild erosion and moderate erosion reduce, while it can be found that the area of strong erosion, very strong erosion, and severe erosion increase.

The spatial changes of soil erosion intensity are presented in Fig. 4. The expansion of the slight erosion area is obvious in the project region. Another obvious change is the emergence of some linear erosion areas which are steep slopes created after land consolidation. By comparing Fig. 4 and Fig. 5, it is clear that the expansion of the slight erosion area was accompanied by the increase of terrace and river-nearby land and the decrease of slope cropland and other lands. It is also found that the emerging linear erosion places are mainly field ridges. Moreover, the village land and its surroundings suffered

Table 2 Mean factor value before and after consolidation

\begin{tabular}{ccc}
\hline Factor & Before consolidation & After consolidation \\
\hline$R$ & 84.00 & 84.00 \\
$K$ & 0.05 & 0.05 \\
$L S$ & 3.18 & 3.31 \\
$C$ & 0.27 & 0.32 \\
$P$ & 0.67 & 0.37 \\
Result $A\left(\mathrm{t} /\left(\mathrm{km}^{2} \cdot \mathrm{yr}\right)\right)$ & 551.87 & 497.39
\end{tabular}

Note: unit conversion factor $=224.2($ Renard et al., 1997)

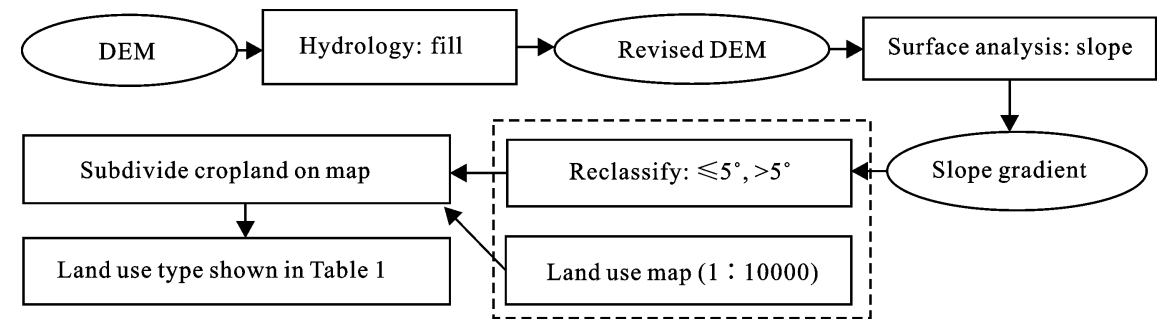

Fig. 3 Work flow for land use type

Table 3 Soil erosion intensity before and after consolidation

\begin{tabular}{|c|c|c|c|c|c|}
\hline Grade & Erosion intensity & Range $\left(\mathrm{t} /\left(\mathrm{km}^{2} \cdot \mathrm{yr}\right)\right)$ & Before consolidation (\%) & After consolidation (\%) & Increment \\
\hline 1 & Slight erosion & $0 \leq A<1000$ & 85.74 & 91.18 & 5.44 \\
\hline 2 & Mild erosion & $1000 \leq A<2500$ & 7.81 & 3.12 & -4.69 \\
\hline 3 & Moderate erosion & $2500 \leq A<5000$ & 3.69 & 2.11 & -1.58 \\
\hline 4 & Strong erosion & $5000 \leq A<8000$ & 1.49 & 1.67 & 0.18 \\
\hline 5 & Very strong erosion & $8000 \leq A<15000$ & 1.03 & 1.46 & 0.43 \\
\hline 6 & Severe erosion & $15000 \leq A$ & 0.24 & 0.46 & 0.22 \\
\hline
\end{tabular}

Note: referred to Ministry of Water Resources of China Standards for Classification and Gradation of Soil Erosion (SL190-2007) 


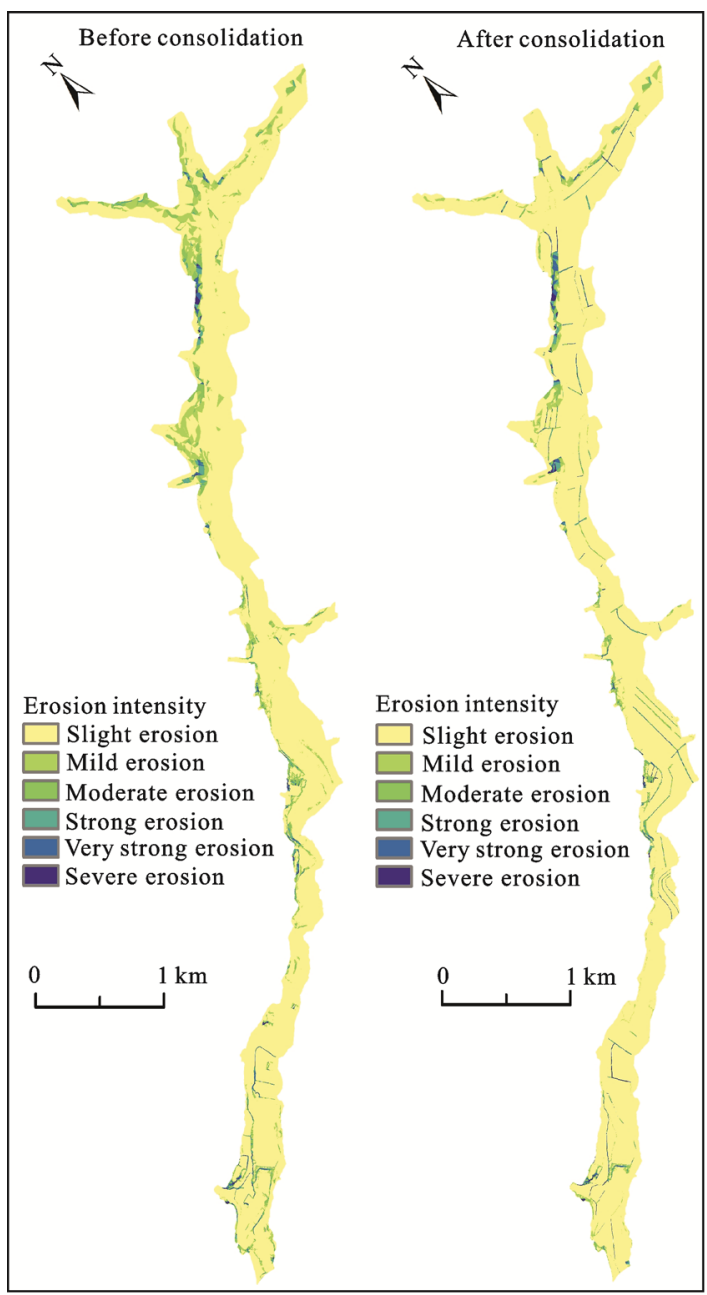

Fig. 4 Soil erosion intensity before and after consolidation

strong erosion, very strong erosion, or even severe erosion both before and after consolidation. Field ridges also suffer strong erosion or more, while terrace and river-nearby land are in slight soil erosion.

\subsection{Soil erosion of different slopes}

By making reclassification and zonal statistics in ArcGIS on raster layer $A$ according to six grades as shown in Table 4,

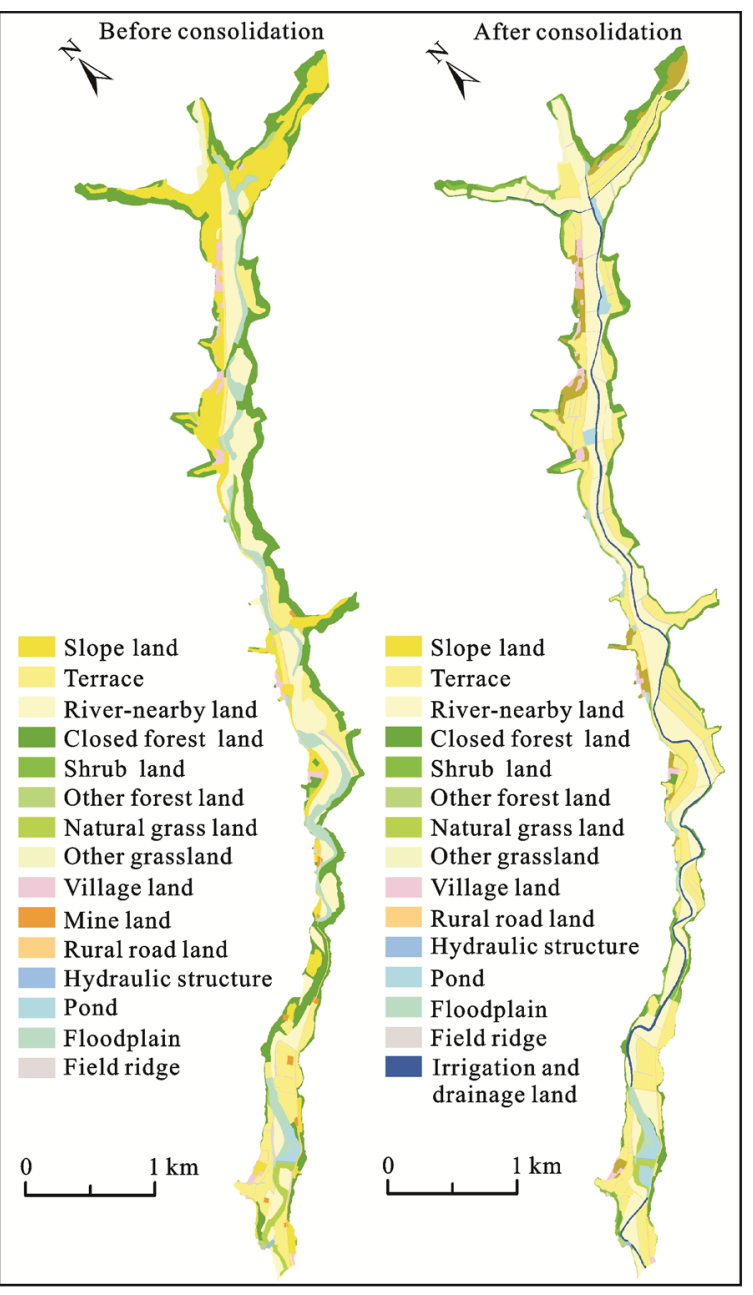

Fig. 5 Land use type before and after consolidation

the gradient distribution in the project region is found. On the one hand, the proportion of $0^{\circ}-5^{\circ}$ grade increases from $64.28 \%$ to $71.69 \%$, the proportions of $15^{\circ}-25^{\circ}, 25^{\circ}-35^{\circ}$, and above $35^{\circ}$ grades raise in different degree, respectively. On the other hand, the proportions of $5^{\circ}-8^{\circ}$ and $8^{\circ}-15^{\circ}$ grades decrease from $15.16 \%$ to $7.13 \%$ and from $13.17 \%$ to $9.82 \%$, respectively. Meanwhile, the average soil erosion modulus of every gradient grade all decreases.

Table 4 Soil erosion of different slopes before and after consolidation

\begin{tabular}{|c|c|c|c|c|}
\hline \multirow{2}{*}{ Gradient grade } & \multicolumn{2}{|c|}{ Proportion of every gradient grade (\%) } & \multicolumn{2}{|c|}{ Average soil erosion modulus $\left(\mathrm{t} /\left(\mathrm{km}^{2} \cdot \mathrm{yr}\right)\right)$} \\
\hline & Before consolidation & After consolidation & Before consolidation & After consolidation \\
\hline $0^{\circ}-5^{\circ}$ & 64.28 & 71.69 & 99.53 & 20.52 \\
\hline $5^{\circ}-8^{\circ}$ & 15.16 & 7.13 & 522.97 & 396.38 \\
\hline $8^{\circ}-15^{\circ}$ & 13.17 & 9.82 & 1401.25 & 1081.67 \\
\hline $15^{\circ}-25^{\circ}$ & 4.98 & 6.45 & 3000.07 & 2442.64 \\
\hline $25^{\circ}-35^{\circ}$ & 1.72 & 2.87 & 4955.34 & 3932.28 \\
\hline Above $35^{\circ}$ & 0.69 & 2.05 & 6636.34 & 5489.08 \\
\hline
\end{tabular}


As for the total changes of the gradient distribution, it is obvious that the area of $5^{\circ}-15^{\circ}$ grade decreases significantly while the area of $0^{\circ}-5^{\circ}$ grade increases greatly. It indicates that the GLCP in Wangjiagou project region was mainly conducted on the area below $15^{\circ}$ as the slopes below $15^{\circ}$ were converted to the terrace and river-nearby land lied in $0^{\circ}-5^{\circ}$ grade.

\subsection{Soil erosion of different land use types}

The soil erosion in different land use types is presented in Table 5 by making reclassification and zonal statistics on raster layer $A$ according to land use types in ArcGIS. The soil erosion of the village land is the most intensive after consolidation, and increases from $6585.72 \mathrm{t} /\left(\mathrm{km}^{2} \cdot \mathrm{yr}\right)$ to $8056.16 \mathrm{t} /\left(\mathrm{km}^{2} \cdot \mathrm{yr}\right)$. Field ridge suffers second intensive soil erosion from $4736.19 \mathrm{t} /\left(\mathrm{km}^{2} \cdot \mathrm{yr}\right)$ up to $6729.94 \mathrm{t} /\left(\mathrm{km}^{2} \cdot \mathrm{yr}\right)$. Hydraulic structure follows up from $2811.32 \mathrm{t} /\left(\mathrm{km}^{2} \cdot \mathrm{yr}\right)$ to $3309.5684 \mathrm{t} /\left(\mathrm{km}^{2} \cdot \mathrm{yr}\right)$. Other land use types are in slight soil erosion or mild soil erosion.

Cropland as the primary land use type increases from $55.54 \%$ to $66.66 \%$ in the project region and is divided into slope cropland, terrace, and river-nearby cropland (Table 5). It is obvious that the slope cropland unsuitable for farming decreases from $21.21 \%$ to $4.92 \%$, while more terrace and river-nearby land favorable for farming are created, increasing from $12.69 \%$ to $29.73 \%$, and from $21.64 \%$ to $32.01 \%$, respectively. The proportions of closed forest land, other forest land, natural grass- land, other grassland, mine land, hydraulic structure and flood plain decrease after consolidation.

Meanwhile, it can be found that shrub land, pond, irrigation and drainage land, and field ridge increase respectively. Comparing with the results in Fig. 4, it is further proved that slope cropland and other lands such as scattered closed forest land, other forest land, natural grassland, other grassland, mine land, floodplain in the gully were mainly converted to terrace and river-nearby land. Mine land was reclaimed totally while irrigation and drainage channels were built mainly on floodplain or natural grassland. The increase of shrub land was mainly attributed to the reduction of scattered steep slope cropland after consolidation around terrace.

\section{Discussion}

\subsection{Multiple effects of GLCP}

The GLCP design in Wangjiagou project region mainly includes land consolidation engineering, irrigation and drainage engineering, rural roads engineering, farmland protection and ecological environment conservation engineering (Table 6). One damaged silt dam was repaired in the project region to offer security. Due to the integrated design, the GLCP tends to bring multiple favorable effects. First, soil erosion becomes decreased. The total amount of soil shipment has decreased by $9.87 \%$ and the area of slight erosion expanded by $5.44 \%$.

Table 5 Soil erosion in different land use types before and after consolidation

\begin{tabular}{|c|c|c|c|c|c|c|c|}
\hline \multirow{2}{*}{ Code } & \multirow{2}{*}{ Land classification } & \multicolumn{3}{|c|}{ Average soil erosion modulus $\left(\mathrm{t} /\left(\mathrm{km}^{2} \cdot \mathrm{yr}\right)\right)$} & \multicolumn{3}{|c|}{ Proportion of land use type (\%) } \\
\hline & & Before consolidation & After consolidation & Increment & Before consolidation & After consolidation & Increment \\
\hline 11 & Slope cropland & 1178.08 & 1645.90 & 467.82 & 21.21 & 4.92 & -16.29 \\
\hline 12 & Terrace & 50.94 & 37.33 & -13.61 & 12.69 & 29.73 & 17.04 \\
\hline 13 & River-nearby land & 34.65 & 21.06 & -13.59 & 21.64 & 32.01 & 10.37 \\
\hline 21 & Closed forest land & 14.78 & 24.89 & 10.11 & 25.26 & 13.44 & -11.82 \\
\hline 22 & Shrub land & 182.94 & 714.49 & 531.55 & 0.60 & 3.05 & 2.45 \\
\hline 23 & Other forest land & 1043.53 & 1422.94 & 379.41 & 0.38 & 0.28 & -0.10 \\
\hline 31 & Natural grassland & 1488.72 & 2447.84 & 959.12 & 1.52 & 0.87 & -0.65 \\
\hline 32 & Other grassland & 1377.21 & 1093.03 & -284.18 & 1.12 & 0.75 & -0.37 \\
\hline 41 & Village land & 6585.72 & 8056.16 & 1470.44 & 2.07 & 2.07 & 0.00 \\
\hline 42 & Mine land & 3850.53 & 0.00 & -3850.53 & 0.49 & 0.00 & -0.49 \\
\hline 43 & Rural road land & 42.63 & 128.39 & 85.76 & 1.57 & 1.86 & 0.29 \\
\hline 44 & Hydraulic structure & 2811.32 & 3309.56 & 498.24 & 0.13 & 0.08 & -0.05 \\
\hline 51 & Pond & 1.27 & 19.08 & 17.81 & 0.71 & 2.20 & 1.49 \\
\hline 52 & Floodplain & 866.66 & 1784.91 & 918.25 & 9.42 & 2.06 & -7.36 \\
\hline 53 & Irrigation and drainage land & 0.00 & 37.46 & 37.46 & 0.00 & 4.07 & 4.07 \\
\hline 54 & Field ridge & 4736.19 & 6729.94 & 1993.75 & 1.19 & 2.61 & 1.42 \\
\hline
\end{tabular}


Table 6 Engineering design list

\begin{tabular}{ll}
\hline \multicolumn{1}{c}{ Engineering design } & Content \\
\hline Key engineering & $\begin{array}{l}\text { Build and repair small and medium key dam, or silt dam } \\
\text { Create new large farming plots (including river-nearby land and broad-base terrace), } \\
\text { and maintain soil fertility and protect topsoil }\end{array}$ \\
Land consolidation engineering & $\begin{array}{l}\text { Build water pool, water cellar, sedimentation tanks, flood diversion canal, alkali diversion canal, } \\
\text { culvert pipe, rural bridge, and drop water }\end{array}$ \\
Irrigation and drainage engineering & $\begin{array}{l}\text { Build second-grade field road, production road, and culvert } \\
\text { Pural roads engineering }\end{array}$ \\
$\begin{array}{l}\text { Farmland protection and ecological } \\
\text { environment conservation engineering }\end{array}$ & intercepting ditch, and drainage ditch
\end{tabular}

Nonetheless, soil erosion increases in certain places such as field ridge, village land, floodplain, natural grassland, and shrub land. Second, lots of large flat farmlands are created to improve agricultural productivity and promote agricultural modernization. Terraces and river-nearby land favorable for farming increase by $17.04 \%$ and $10.37 \%$, respectively. The improving production conditions would advance local agricultural development so as to raise income of local peasants and economic growth. Third, lots of large flat farmland increased by the GLCP would indirectly reduce the land reclamation on the slopes, which can efficiently protect local ecological vulnerable environment.

\subsection{GLCP and GFG}

Zhu (1998) presented a strategy for land consolidation on the Loess Plateau: 1) rainfall should be retained and infiltrated to site; 2) grain should be cultivated on the plains and tablelands; 3 ) wood and fruit trees should be located in gullies; 4) grasses and shrubs should be planted on hillsides. Liu (1999) proposed four principles for land consolidation and divided the process of constructing conservational and eco-agricultural system into three phases: initial restoration stage, stable improvement stage and fine development stage. During the past decades, great efforts have been made to restore vegetation so as to reduce soil erosion in the Loess Plateau. However, the efficiency of vegetation restoration was not achieved as expected (Shi and Shao, 2000). The situation has been improved a lot after the GFG project was implemented (Chen et al., 2007; Wang et al., 2013).

With the vegetation cover increasing and soil erosion decreasing because of the GFG project, two changes should be recognized: 1) The increasing vegetation coverage not only reduces soil erosion, but also minimizes the flood risks (Zuazo and Pleguezuelo, 2008), which is important for the safety of dams and land in gullies. The
Wangjiagou project region has a high vegetation coverage created partly by the GFG, which could prevent the heavy floods greatly. Thus, the GFG laid a solid basis for the GLCP; 2) With soil erosion decreasing due to the GFG project, it will take longer time to form dam land (one kind of most fertile river-nearby land, usually formed in front of dam through soil accumulation) naturally, which means short-term economic benefits are not easy to achieve. The siltation of medium silt dam or key silt dam will take more than about a decade to create new dam land. Thus, it becomes necessary to improve ways to create dam land. Plenty of large flat farmlands were created in the Wangjiagou project region in a relatively short period. The GLCP developed one feasible way to new generation dam land.

The improving ecological environment constructed by the GFG offered certain security for land consolidation in the Loess Plateau. Meanwhile, more farming land in gullies created by the GLCP instead of land reclamation on the slopes also guarantees the valuable achievements of the GFG. On the basis of the GFG, the GLCP tends to combine long-term and short-term benefits as well as economic development and ecological protection. Under the background of ecological civilization construction in China, the Loess Plateau hilly region especially Yan'an City should continue to promote 'three engineering' such as the GLCP, the GFG, and land creation for building city, optimize 'three spaces' including ecology, production and living, and speed up the construction of 'Yan'an model' with man-earth harmony, urban-rural coordination and innovative development in the future.

\section{Conclusions}

This study assesses the effects of the GLCP on soil erosion by using a GIS-based RUSLE. It is feasible to im- 
plement the GIS-based RUSLE model and the data acquired by field measure to assess the effects in smaller areas. The data in this way are much accessible and fully utilized for the assessment of soil erosion in the real land consolidation projects.

It is obvious that the GLCP in Wangjiagou project region has positive effect on soil erosion reduction, and the soil erosion intensity in Wangjiagou project region reduces significantly as well. Meanwhile, more terrace and river-nearby land favorable for farming are created, accompanied by the decrease of slope cropland unsuitable for farming. The results of this study also show that slopes below $15^{\circ}$ are feasible to be consolidated in GLCP.

It is indicated that the relationship between the GLCP and the GFG tends to be mutually beneficial and inseparable in Wangjiagou project region. The GFG promotes the high vegetation coverage which minimizes the floods greatly to prevent project damages in gullies, while the GLCP creates more farmlands favorable for farming instead of land reclamation on slopes. However, the GLCP also intensifies soil erosion in certain places in the project region. It is worth noting that village land still suffers soil erosion and field ridge ever suffers stronger soil erosion even after consolidation. Thus, special improvement in the GLCP design is needed possibly for intensified soil erosion areas. Furthermore, due to diversity of gullies in the Loess Plateau, the concrete design varies flexibly according to every gully situation and not all the gullies are suitable to conduct the GLCP.

\section{References}

Bennett M T, 2008. China's sloping land conversion program: institutional innovation or business as usual? Ecological Economics, 65(4): 699-711. doi: 10.1016/j.ecolecon.2007.09.017

Bettinger R L, Barton L, Richerson P J et al., 2007. The transition to agriculture in northwestern China. Developments in Quaternary Sciences, 9: 83-101. doi: 10.1016/S1571-0866(07) 09008-2

Bonilla C A, Reyes J L, Magri A, 2010. Water erosion prediction using the revised universal soil loss equation (RUSLE) in a GIS framework, central Chile. Chilean Journal of Agricultural Research, 70(1): 159-169. doi: 10.4067/S0718-58392010000 100017

Cao S X, Xu C G, Chen L et al., 2009. Attitudes of farmers in China's northern Shaanxi Province towards the land-use changes required under the Grain for Green Project, and implications for the project's success. Land Use Policy, 26(4): 1182-1194. doi: 10.1016/j.landusepol.2009.02.006

Chen L D, Wei W, Fu B J et al., 2007. Soil and water conserva- tion on the Loess Plateau in China: review and perspective. Progress in Physical Geography, 31(4): 389-403. doi: 10. 1177/0309133307081290

Chen L D, Yang L, Wei W et al., 2013. Towards sustainable integrated watershed ecosystem management: a case study in Dingxi on the Loess Plateau, China. Environmental Management, 51(1): 126-137. doi: 10.1007/s00267-011-9807-0

Chen T, Niu R Q, Li P X et al., 2011. Regional soil erosion risk mapping using RUSLE, GIS, and remote sensing: a case study in Miyun Watershed, North China. Environmental Earth Sciences, 63(3): 533-541. doi: 10.1007/s12665-010-0715-z

De Bruin S, Stein A, 1998. Soil-landscape modeling using fuzzy c-means clustering of attributes data derived from a Digital Elevation Model (DEM). Geoderma, 83(1): 17-33. doi: 10.1016/S0016-7061(97)00143-2

Deng L, Shangguan Z P, Li R, 2012. Effects of the grainfor-green program on soil erosion in China. International Journal of Sediment Research, 27(1): 120-127. doi: 10.1016/ S1001-6279(12)60021-3

Erdogan E H, Erpul G, Bayramin I, 2007. Use of USLE/GIS methodology for predicting soil loss in a semiarid agricultural environment. Environmental Monitoring and Assessment, 131(1-3): 153-161. doi: 10.1007/s10661-006-9464-6

Fistikoglu O, Harmancioglu N B, 2002. Integration of GIS with USLE in assessment of soil erosion. Water Resources Management, 16(6): 447-467. doi: 10.1023/A:1022282125760

$\mathrm{Fu}$ B J, 1989. Soil erosion and its control in the Loess Plateau of China. Soil Use and Management, 5(2): 76-82. doi: 10.1111/j.1475-2743.1989.tb00765.x

Fu B J, Liu Y, Lü Y H et al., 2011. Assessing the soil erosion control service of ecosystems change in the Loess Plateau of China. Ecological Complexity, 8(4): 284-293. doi: 10.1016/ j.ecocom.2011.07.003

Guo Y J, Liu Y S, Wen Q et al., 2014. The transformation of agricultural development towards a sustainable future from an evolutionary view on the Chinese Loess Plateau: a case study of Fuxian County. Sustainability, 6(6): 3644-3668. doi: $10.3390 / \mathrm{su} 6063644$

Hou L L, Hoag D, Keske C M H et al., 2014. Sustainable value of degraded soils in China's Loess Plateau: an updated approach. Ecological Economics, 97(1): 20-27. doi: 10.1016/j.ecolecon. 2013.10.013

Irvem A, Topaloğlu F, Uygur V, 2007. Estimating spatial distribution of soil loss over Seyhan River Basin in Turkey. Journal of Hydrology, 336(1): 30-37. doi: 10.1016/j.jhydrol.2006. 12.009

Lee S, 2004. Soil erosion assessment and its verification using the universal soil loss equation and geographic information system: a case study at Boun, Korea. Environmental Geology, 45(4): 457-465. doi: 10.1007/s00254-003-0897-8

Li Ruipu, Lu Xinhai, Gu Xiaokun, 2010. GIS application in earthwork calculation and distribution within farmland consolidation project. China Land Science, 24(6): 68-73. (in Chinese)

Liang Y C, Li S Z, Feldman M W et al., 2012. Does household composition matter? The impact of the Grain for Green Pro- 
gram on rural livelihoods in China. Ecological Economics, 75(3): 152-160. doi: 10.1016/j.ecolecon.2012.01.019

Liu B Y, Nearing M A, Shi P J et al., 2000. Slope length effects on soil loss for steep slopes. Soil Science Society of America Journal, 64(5): 1759-1763. doi: 10.2136/sssaj2000.6451759x

Liu Baoyuan, Zhang Keli, Jiao Juying, 1999. Soil erodibility and its use in soil erosion prediction model. Journal of Natural Resources, 14(4): 345-350. (in Chinese)

Liu Changshun, Qi Shi, Du Lijuan, 2003. Method to calculate earthwork in land consolidation project. Science of Soil and Water Conservation, 1(2): 77-79. (in Chinese)

Liu G B, 1999. Soil conservation and sustainable agriculture on the Loess Plateau: challenges and prospects. Ambio, 28(8): 663-668.

Liu Q, Wang Y Q, Zhang J et al., 2013. Filling gullies to create farmland on the Loess Plateau. Environmental Science \& Technology, 47(14): 7589-7590. doi: 10.1021/es402460r

Liu Y S, Fang F, Li Y H, 2014. Key issues of land use in China and implications for policy making. Land Use Policy, 40(5): 6-12. doi: 10.1016/j.landusepol.2013.03.013

Liu Y S, Li Y H, 2014. China's land creation project stands firm. Nature, 511(7510): 410-410. doi: 10.1038/511410c

Liu Y S, Zhang Y Y, Guo L Y, 2010. Towards realistic assessment of cultivated land quality in an ecologically fragile environment: a satellite imagery-based approach. Applied Geography, 30(2): 271-281. doi: 10.1016/j.apgeog.2009.07.002

Long H L, Liu Y S, Li X B, 2010. Building new countryside in China: a geographical perspective. Land Use Policy, 27(2): 457-470. doi: 10.1016/j.landusepol.2009.06.006

Miao C Y, Yang L, Chen X H et al., 2012. The vegetation covers dynamics (1982-2006) in different erosion regions of the Yellow River Basin, China. Land Degradation \& Development, 23(1): 62-71. doi: 10.1002/1dr.1050

Ostwald M, Chen D L, 2006. Land-use change: impacts of climate variations and policies among small-scale farmers in the Loess Plateau, China. Land Use Policy, 23(4): 361-371. doi: 10.1016/j.landusepol.2005.04.004

Prasannakumar V, Vijith H, Abinod S et al., 2012. Estimation of soil erosion risk within a small mountainous sub-watershed in Kerala, India, using Revised Universal Soil Loss Equation (RUSLE) and geo-information technology. Geoscience Frontiers, 3(2): 209-215. doi: 10.1016/j.gsf.2011.11.003

Qin Wei, Zhu Qingke, Zhang Yan, 2009. Soil erosion assessment of small watershed in Loess Plateau based on GIS and RUSLE. Transactions of the Chinese Society of Agricultural Engineering, 25(8): 157-162. (in Chinese)

Renard K G, Foster G R, Weesies G A et al., 1997. Predicting Soil Erosion by Water: A Guide to Conservation Planning with the Revised Universal Soil Loss Equation (RUSLE). Washington, DC, USA: Agriculture Handbook No. 703, USDA-ARS.

Ritsema C J, 2003. Introduction: Soil erosion and participatory land use planning on the Loess Plateau in China. $\mathrm{Ca}$ - tena, 54(1): 1-5. doi: 10.1016/S0341-8162(03)00052-3

Shi H, Shao M A, 2000. Soil and water loss from the Loess Plateau in China. Journal of Arid Environments, 45(1): 9-20. doi: 10.1006/jare.1999.0618

Tong Xinqi, Xu Yanling, Li Huai'en et al., 2006. Effect of soil and water conservation measurements in the Xiangyanggou watershed. Bulletin of Soil and Water Conservation, 26(5): 86-93. (in Chinese)

Uchida E, Xu Jintao, Xu Zhigang et al., 2007. Are the poor benefiting from China's land conservation program? Environment and Development Economics, 12(4): 593-620. doi: 10.1017/ S1355770X07003713

Wang J Y, Liu Y S, Liu Z G, 2013. Spatio-temporal pattern of cropland conversion in response to the 'Grain for Green Project' in China's Loess Hilly Region of Yanchuan County. Remote Sensing, 5(11): 5642-5661. doi: 10.3390/rs5115642

Wang L, Shao M A, Wang Q J et al., 2006. Historical changes in the environment of the Chinese Loess Plateau. Environmental Science \& Policy, 9(7-8): 675-684. doi: 10.1016/j.envsci. 2006.08.003

Wischmeier W H, Johnson C B, Cross B V, 1971. Soil erodibility nomograph for farmland and construction sites. Soil \& Water Conservation, 26(5): 189-193.

Wischmeier W H, Smith D D, 1978. Predicting Rainfall Erosion Losses-A Guide to Conservation Planning. Washington, DC, USA: Agriculture Handbook No. 537. US Department of Agriculture Science and Education Administration.

Yang Wenzhi, Yu Cunzu, 1992. Regional Treatment and Evaluation in Loess Plateau. Beijing: Science Press. (in Chinese).

Zhang Yan, Liu Baoyuan, Shi Peijun et al., 2001. Crop cover factor estimating for soil loss prediction. Acta Ecologica Sinica, 21(7): 1050-1056. (in Chinese)

Zhang Y, Liu B Y, Zhang Q C et al., 2003. Effect of different vegetation types on soil erosion by water. Acta Botanica Sinica, 45(10): 1204-1209. doi: 10.3321/j.issn:1672-9072. 2003.10.009

Zhao Minghan, 1989. Yan'an Soil. Xi'an: Xi'an Map Press. (in Chinese)

Zhou D C, Zhao S Q, Zhu C, 2012. The Grain for Green Project induced land cover change in the Loess Plateau: a case study with Ansai County, Shaanxi Province, China. Ecological Indicators, 23(12): 88-94. doi: 10.1016/j.ecolind.2012.03.021

Zhou Hongjian, Wang Jinai, Li Rui et al., 2008. Analysis of effects of 'Grain for Green' program using temporal NDVI and rainfall series. Journal of Soil and Water Conservation, 22(4): 70-74. (in Chinese)

Zhu Xianmo, 1998. The theory and practice of '28 Character Strategy' in Loess Plateau land treatment. Bulletin of the Chinese Academy of Sciences, 13(3): 232-256. (in Chinese)

Zuazo V H D, Pleguezuelo C R R, 2008. Soil-erosion and runoff prevention by plant covers: a review. Agronomy for Sustainable Development, 28(1): 65-86. doi: 10.1007/978-90-4812666-8_48 